\title{
Effects of 24-Epibrassinolide on In Vitro Micropropagation of Highbush Blueberry
}

\author{
O. A. Kudryashova ${ }^{a}$, A. A. Volotovich ${ }^{a}$, T. I. Vasilevskaya ${ }^{b}$, N. P. Varavina ${ }^{b}$, \\ Zh. A. Rupasova ${ }^{b}$, and V. A. Khripach ${ }^{c}$ \\ ${ }^{a}$ Polesye State University, ul. Dneprovskoi Flotilii 23, Pinsk, 225710 Belarus; \\ fax: 7(375-165) 31-2195; e-mail: volant777@tut.by \\ ${ }^{b}$ Central Botanical Garden, National Academy of Sciences of Belarus, Minsk, Belarus \\ ${ }^{c}$ Institute of Bioorganic Chemistry, National Academy of Sciences of Belarus, Minsk, Belarus \\ Received July 21, 2011
}

\begin{abstract}
In order to elucidate effects of 24-epibrassinolide (EB) on the efficiency of in vitro regeneration of highbush blueberry (Vaccinium corymbosum L., cv. Brigitta blue), we analyzed variability of seven bioproductive parameters in regenerant plants cultured on nutrient media differing in hormonal composition. The additive action of EB, cytokinin (2iP), and auxin (IAA) was discovered for several parameters, such as reproduction coefficient, weight of regenerant plants, and the content of anthocyanin pigments. The greatest reproduction coefficients were noted in regenerant plants cultured on the medium containing $0.25 \mathrm{mg} / \mathrm{L} \mathrm{EB}$, $7.25 \mathrm{mg} / \mathrm{L} 2 \mathrm{iP}$, and $1.00 \mathrm{mg} / \mathrm{L} \mathrm{IAA}$, as well as on the medium with $0.05 \mathrm{mg} / \mathrm{L} \mathrm{EB}, 2.00 \mathrm{mg} / \mathrm{L} 2 \mathrm{iP}$, and $0.50 \mathrm{mg} / \mathrm{L}$ IAA. It is suggested that low concentrations of $2 \mathrm{iP}$ and $\mathrm{EB}$, applied in certain combinations, can be used for the industrial in vitro propagation of regenerant plants of highbush blueberry varieties.
\end{abstract}

Keywords: Vaccinium corymbosum, 24-epibrassinolide, IAA, 6- $(\gamma, \gamma$-dimethylallylamino)purine, anthocyanins, in vitro micropropagation.

DOI: $10.1134 / \mathrm{S} 1021443712040073$

\section{INTRODUCTION}

Brassinosteroids (steroid plant hormones, BS) are a promising group of natural plant growth regulators [1]. They are derivatives of oxysteroids with a lactone group in the ring B. The intracellular pathway of signal transduction and regulation of gene expression are initiated by binding of BS molecule to the plant cell membrane receptor representing the BRI1-BAK1kinase complex $[2,3]$. The activated receptor switches on the cascade of phosphorylation reactions, which inhibits BIN2-kinase activity and promotes accumulation of active dephosphorylated transcription factors BES1 and BZR1 [4]. In the plant cell nucleus, the transcription factors recognize and bind to nucleotide sequences of promoter zone of target genes, thus commencing the expression of these genes.

Brassinosteroids stimulate various physiological processes in plant cells, including membrane potential changes, photosynthetic and enzymatic activity, and the phytohormone balance [5]. The effects of BS on plant growth and development show a trend of syner-

Abbreviations: $\quad 2 \mathrm{iP}-6-(\gamma, \gamma$-dimethylallylamino $)$ purine; $\quad \mathrm{BS}-$ brassinosteroids; EB-24-epibrassinolide; GA—genuine anthocyanins; LA-leucoanthocyanins; $\mathrm{RC}_{\mathrm{E}}$-reproduction coefficient for explants; $\mathrm{RC}_{\mathrm{S}}$ - reproduction coefficient for shoots; TAP - total content of anthocyanin pigments; WPM - nutrient woody plant medium. gism with other phytohormones, auxins in particular [4]. Regulation of plant cell growth and differentiation mediated by BS intensifies geotropic responses and accelerates stem elongation, leaf development, and pollen tube growth. It promotes xylem differentiation and pollen vitality, decelerates leaf senescence, and improves plant resistance to stresses [6,7].

Highbush blueberry is a promising species for industrial-scale culturing under climatic conditions of Belarus, especially in the southern agroclimatic zone [8]. Clonal micropropagation of plant species from the genus Vaccinium is considered an important platform for inventing modern technologies of rapid industrial production of high-grade planting stock. Studies performed in the Research Laboratory of Cell Technologies in Plant Growing (Polesye State University) in 2009-2011 [9] have modified conventional approaches to clonal micropropagation of highbush blueberry adopted in Belarus [10]. In particular, the composition of nutrient media was improved and production of planting stock became technologically more effective (Industrial Patent Application no. A20110076 of 20.01.2011, Belarus) [11].

This paper deals with the bioproductive characteristics of regenerant highbush blueberry plants (cv. Brigitta blue) propagated axenically in vitro on nutrient media with different hormonal composition, spe- 
Table 1. Composition of agarized nutrient media

\begin{tabular}{|c|c|c|}
\hline $\begin{array}{c}\text { Number } \\
\text { of the treatment }\end{array}$ & Variant & Medium composition \\
\hline 1 & Control 1 (common reference) & without phytohormones \\
\hline 2 & Control 2 & $7.25 \mathrm{mg} / \mathrm{L} 6-(\gamma, \gamma$-dimetylallylamino)purine (2iP) \\
\hline 3 & Control 3 & $1.00 \mathrm{mg} / \mathrm{L} \mathrm{IAA}$ \\
\hline 4 & Control 4 & $7.25 \mathrm{mg} / \mathrm{L} 2 \mathrm{iP}, 1.00 \mathrm{mg} / \mathrm{L} \mathrm{IAA}$ \\
\hline 5 & Experiment & $0.05 \mathrm{mg} / \mathrm{L} 24$-epibrassinolide (EB) \\
\hline 6 & $"$ & $0.15 \mathrm{mg} / \mathrm{L} \mathrm{EB}$ \\
\hline 7 & $"$ & $0.25 \mathrm{mg} / \mathrm{L} \mathrm{EB}$ \\
\hline 8 & $"$ & $0.05 \mathrm{mg} / \mathrm{L} \mathrm{EB}, 7.25 \mathrm{mg} / \mathrm{L} 2 \mathrm{iP}, 1.00 \mathrm{mg} / \mathrm{L} \mathrm{IAA}$ \\
\hline 9 & $"$ & $0.15 \mathrm{mg} / \mathrm{L} \mathrm{EB}, 7.25 \mathrm{mg} / \mathrm{L} 2 \mathrm{iP}, 1.00 \mathrm{mg} / \mathrm{L} \mathrm{IAA}$ \\
\hline 10 & $"$ & $0.25 \mathrm{mg} / \mathrm{L} \mathrm{EB}, 7.25 \mathrm{mg} / \mathrm{L} 2 \mathrm{iP}, 1.00 \mathrm{mg} / \mathrm{L} \mathrm{IAA}$ \\
\hline 11 & $"$ & $0.05 \mathrm{mg} / \mathrm{L} \mathrm{EB}, 2.00 \mathrm{mg} / \mathrm{L} 2 \mathrm{iP}, 1.00 \mathrm{mg} / \mathrm{L} \mathrm{IAA}$ \\
\hline 12 & $"$ & $0.15 \mathrm{mg} / \mathrm{L} \mathrm{EB}, 2.00 \mathrm{mg} / \mathrm{L} 2 \mathrm{iP}, 1.00 \mathrm{mg} / \mathrm{L}$ IAA \\
\hline 13 & $"$ & $0.25 \mathrm{mg} / \mathrm{L} \mathrm{EB}, 2.00 \mathrm{mg} / \mathrm{L} 2 \mathrm{iP}, 1.00 \mathrm{mg} / \mathrm{L}$ IAA \\
\hline 14 & $"$ & $0.05 \mathrm{mg} / \mathrm{L} \mathrm{EB}, 2.00 \mathrm{mg} / \mathrm{L} 2 \mathrm{iP}, 0.50 \mathrm{mg} / \mathrm{L} \mathrm{IAA}$ \\
\hline 15 & $"$ & $0.15 \mathrm{mg} / \mathrm{L} \mathrm{EB}, 2.00 \mathrm{mg} / \mathrm{L} 2 \mathrm{iP}, 0.50 \mathrm{mg} / \mathrm{L} \mathrm{IAA}$ \\
\hline 16 & $"$ & $0.25 \mathrm{mg} / \mathrm{L} \mathrm{EB}, 2.00 \mathrm{mg} / \mathrm{L} 2 \mathrm{iP}, 0.50 \mathrm{mg} / \mathrm{L} \mathrm{IAA}$ \\
\hline 17 & $"$ & $0.05 \mathrm{mg} / \mathrm{L} \mathrm{EB}, 2.00 \mathrm{mg} / \mathrm{L} 2 \mathrm{iP}$ \\
\hline 18 & $"$ & $0.15 \mathrm{mg} / \mathrm{L} \mathrm{EB}, 2.00 \mathrm{mg} / \mathrm{L} 2 \mathrm{iP}$ \\
\hline 19 & $"$ & $0.25 \mathrm{mg} / \mathrm{L} \mathrm{EB}, 2.00 \mathrm{mg} / \mathrm{L} 2 \mathrm{iP}$ \\
\hline
\end{tabular}

cifically, at various concentrations of 24-epibrassinolide.

\section{MATERIALS AND METHODS}

Investigations were conducted in the Research Laboratory of Cell Technologies in Plant Growing (Polesye State University) in January-March, 2011.

We used in vitro propagated regenerant plants of late-ripening highbush blueberry (Vaccinium corymbosum L., cv. Brigitta blue). At least 80 regenerant plants were sampled for each treatment. Altogether, we accomplished 19 treatments (1520 regenerant plants), including four reference treatments (at least 320 regenerants). The regenerant plants were produced by culturing explants consisting of two metamers in $100-\mathrm{mL}$ cone flasks. Each flask was filled with $25 \mathrm{~mL}$ of sterile agarized nutrient medium prepared on macronutrient- and micronutrient-containing basal medium for woody plants (WPM) [12]. Twenty explants were placed per flask. The treatments applied differed only in the hormonal composition of agarized nutrient medium (Table 1).

All media for reference treatments (1-4) differed in hormonal composition from the standard nutrient medium used routinely for propagation of regenerant plants. The standard medium contained $5.00 \mathrm{mg} / \mathrm{L} \mathrm{6-}$ $(\gamma, \gamma$-dimethylallylamino)purine $(2 \mathrm{iP})$ and $1.00 \mathrm{mg} / \mathrm{L}$ IAA $[9,10]$. In treatments with $2 \mathrm{iP}$ supplements, the experimental media differed from the standard nutrient medium in $2 \mathrm{iP}$ concentration and in the cytokinin : auxin ratio.

The flasks with regenerant plants were placed on shelves in a culturing room of biotechnological laboratory and cultured at $25^{\circ} \mathrm{C}, 16-\mathrm{h}$ photoperiod, illuminance of $6 \mathrm{klx}$ (four OSRAM L36W/76 fluorescent lamps, Natura) and relative humidity of $70 \%$. After 8 weeks of culturing, we measured the height of the shoots of regenerant plants using the plotting paper (GOST 334-73) and calculated the height of regenerants as an average height of all the shoots produced by one regenerant plant. We took into consideration the number of shoots in each regenerant plant and calculated reproduction coefficients $\mathrm{RC}_{\mathrm{S}}$ and $\mathrm{RC}_{\mathrm{E}}$ that designate the number of shoots produced by one explant $\left(\mathrm{RC}_{\mathrm{S}}\right)$ and the number of mature explants $\left(\mathrm{RC}_{\mathrm{E}}\right)$ produced from one regenerant plant and suitable for subsequent propagation. We determined the weight of regenerant plants and assayed the content of genuine anthocyanins (GA) according to Shnaidman and Afanas'eva [13]. The content of leucoanthocyanins 4 (LA) and the total content of anthocyanin pigments (TAP) in regenerant plants were determined according to Swain and Hillis [14]. The content of LA was 5 calculated as a difference between the sum of anthocyanins (TAP) and GA content.

Mathematical analysis of the data (the means \pm standard error, calculation of least significant differ- 
Table 2. Variability of bioproductive characteristics in regenerant plants of highbush blueberry (cv. Brigitta blue) in vitro

\begin{tabular}{|c|c|c|c|c|c|c|c|c|}
\hline No. & Treatment & $\mathrm{RC}_{\mathrm{S}}$ & $\mathrm{RC}_{\mathrm{E}}$ & $\begin{array}{c}\text { Plant } \\
\text { height, } \mathrm{cm}\end{array}$ & $\begin{array}{c}\text { Weight } \\
\text { of regenerant } \\
\text { plant, } g\end{array}$ & $\mathrm{GA}, \mathrm{mg} \%$ & $\mathrm{LA}, \mathrm{mg} \%$ & TAP, mg\% \\
\hline 1 & medium) & \pm 0.2 & \pm 0.6 & & 04 & \pm 6 & 11 & 114 \\
\hline 2 & $2 \mathrm{iP}_{7.25}$ & $4 \pm 0.3$ & $4.8 \pm 0.8$ & $1.77 \pm 0.06$ & $0.039 \pm 0.001$ & $168 \pm 5$ & $2148 \pm 45$ & $2315 \pm 49$ \\
\hline 3 & $\mathrm{IAA}_{1.00}$ & $1.0 \pm 0.1$ & $2.2 \pm 0.3$ & $2.74 \pm 0.17$ & $0.018 \pm 0.001$ & $163 \pm 7$ & $2306 \pm 29$ & $2468 \pm 37$ \\
\hline 4 & $2 \mathrm{iP}_{7.25}+\mathrm{IAA}_{1.00}$ & $4 \pm 0.3$ & $5.2 \pm 0.3$ & $0.93 \pm 0.05$ & $0.036 \pm 0.016$ & $313 \pm 10$ & $2935 \pm 93$ & $3248 \pm 103$ \\
\hline 5 & $\mathrm{~EB}_{0.05}$ & $4 \pm 0.1$ & $2.6 \pm 0.3$ & $2.31 \pm$ & $0.016 \pm 0.007$ & $213 \pm 11$ & 115 & $2998 \pm 126$ \\
\hline 6 & $\mathrm{~EB}_{0.15}$ & \pm 0.1 & $2.8 \pm 0.1$ & $1.89 \pm$ & $0.014 \pm 0.001$ & & & \\
\hline 7 & $\mathrm{~EB}_{0.25}$ & $2.1 \pm 0.3$ & $3.4 \pm 0.4$ & $2.15 \pm 0.12$ & $0.019 \pm 0.007$ & $208 \pm 11$ & $3664 \pm 89$ & $3872 \pm 99$ \\
\hline 8 & $2 \mathrm{iP}_{7.25}+\mathrm{IAA}_{1.00}+\mathrm{EB}_{0.05}$ & $4.7 \pm 0.7$ & $6.9 \pm 1.6$ & $1.00 \pm 0.05$ & $0.030 \pm 0.013$ & $601 \pm 13$ & $4563 \pm 110$ & $5164 \pm 118$ \\
\hline 9 & $2 \mathrm{iP}_{7.25}+\mathrm{IAA}_{1.00}+\mathrm{EB}_{0.15}$ & $4.4 \pm 0.6$ & $6.2 \pm 0.1$ & $0.98 \pm 0.06$ & $0.043 \pm 0.019$ & $296 \pm 32$ & $2798 \pm 69$ & $3095 \pm 102$ \\
\hline 10 & $2 \mathrm{iP}_{7.25}+\mathrm{IAA}_{1.00}+\mathrm{EB}_{0.25}$ & $6.5 \pm 0.5$ & $9.2 \pm 1.2$ & $0.99 \pm 0.04$ & $0.031 \pm 0.010$ & $537 \pm 19$ & $4295 \pm 174$ & $4832 \pm 189$ \\
\hline 11 & $2 \mathrm{iP}_{2.00}+\mathrm{IAA}_{1.00}+\mathrm{EB}_{0.05}$ & $4.0 \pm 0.5$ & $8.2 \pm 0.3$ & $1.82 \pm 0.11$ & $0.067 \pm 0.003$ & $694 \pm 24$ & $3647 \pm 62$ & $4341 \pm 40$ \\
\hline 12 & $2 \mathrm{iP}_{2.00}+\mathrm{IAA}_{1.00}+\mathrm{EB}_{0.15}$ & $5.0 \pm 0.1$ & $8.0 \pm 0.3$ & $1.38 \pm 0.06$ & $0.134 \pm 0.002$ & $773 \pm 7$ & $2859 \pm 44$ & $3633 \pm 37$ \\
\hline 13 & $2 \mathrm{iP}_{2.00}+\mathrm{IAA}_{1.00}+\mathrm{EB}_{0.25}$ & $3.2 \pm 0.1$ & $5.2 \pm 0.1$ & $1.49 \pm 0.08$ & $0.100 \pm 0.017$ & $1133 \pm 24$ & 332 & \pm 49 \\
\hline 14 & $\mathrm{~A}_{0.50}+\mathrm{EB}_{0.05}$ & $5.4 \pm 0.1$ & $9.8 \pm 1.2$ & $1.55 \pm 0.06$ & $0.071 \pm 0.002$ & $575 \pm 38$ & 3016 & $3591 \pm 92$ \\
\hline 15 & $2 \mathrm{iP}_{2.00}+\mathrm{IAA}_{0.50}+\mathrm{EB}_{0.15}$ & $4.1 \pm 0.3$ & $8.0 \pm 1.0$ & $1.70 \pm 0.06$ & $0.084 \pm 0.009$ & $1316 \pm 15$ & $2830 \pm 53$ & $4146 \pm 68$ \\
\hline 16 & $2 \mathrm{iP}_{2.00}+\mathrm{IAA}_{0.50}+\mathrm{EB}_{0.25}$ & $3.9 \pm 0.1$ & $6.9 \pm 0.2$ & $1.72 \pm 0.07$ & $0.091 \pm 0.003$ & $1180 \pm 34$ & $3579 \pm 19$ & $4759 \pm 15$ \\
\hline 17 & $2 \mathrm{iP}_{2.00}+\mathrm{EB}_{0.05}$ & $5.0 \pm 0.1$ & $7.5 \pm 0.8$ & $1.39 \pm 0.06$ & $0.094 \pm 0.003$ & $687 \pm 13$ & $3094 \pm 15$ & $3781 \pm 21$ \\
\hline 18 & $2 \mathrm{iP}_{2.00}+\mathrm{EB}_{0.15}$ & $3.3 \pm 0.2$ & $6.3 \pm 1.0$ & $1.52 \pm 0.09$ & $0.082 \pm 0.013$ & $1180 \pm 42$ & $3413 \pm 19$ & $4593 \pm 46$ \\
\hline 19 & $2 \mathrm{iP}_{2.00}+\mathrm{EB}_{0.25}$ & $3.9 \pm 0.1$ & $6.7 \pm 0.3$ & $1.65 \pm 0.06$ & $0.066 \pm 0.009$ & $893 \pm 44$ & $3599 \pm 11$ & $4492 \pm 45$ \\
\hline $\mathrm{LSD}_{0.05}$ & & 1.0 & 2.0 & 0.25 & 0.025 & 62 & 214 & 244 \\
\hline $\operatorname{LSD}_{0.01}$ & & 1.4 & 2.7 & 0.33 & 0.034 & 83 & 285 & 325 \\
\hline
\end{tabular}

Note: $\mathrm{RC}_{\mathrm{S}}$-reproduction coefficient for shoots; $\mathrm{RC}_{\mathrm{E}}$-reproduction coefficient for explants; $\mathrm{GA}$ - genuine anthocyanins; LA-leucoanthocyanins; TAP — total content of anthocyanin pigments; $\mathrm{mg} \%$ - milligram per $100 \mathrm{~g} \mathrm{fr}$ wt. $\mathrm{LSD}_{0.05}$ - the least significant difference at a significance level $P<0.05 ; \mathrm{LSD}_{0.01}$ - the least significant difference at a significance level $P<0.01$. The above designations apply also to Tables $3-4$.

ences at significance levels of $P<0.05$ and $P<0.01$ ) was performed according to standard methods of variation statistics [15] using statistic analysis software STATISTICA 6.0 [16].

\section{RESULTS}

Table 2 illustrates variability of seven examined parameters of highbush blueberry regenerants in vitro. The presence of cytokinin $2 \mathrm{iP}$ in the nutrient agarized medium (Table 1, treatments 2, 4, 8-19, ) caused a reliable (at $P<0.01$ ) increase in reproduction coefficients for explants $\left(\mathrm{RC}_{\mathrm{E}}\right)$ and shoots $\left(\mathrm{RC}_{\mathrm{S}}\right)$ by a factor of 2.5-5.0 and 3-6, respectively.

When 24-epibrassinolide (EB) was present alone in the nutrient medium at various concentrations (Table 1 , treatments 5-7), the height of regenerant plants increased reliably (at $P<0.01$ ) by $4-8 \mathrm{~mm}$. In the presence of 0.15 and $0.25 \mathrm{mg} / \mathrm{L} \mathrm{EB}$, the content of LA and TAP in regenerant plants increased about 1.2 times (at $P<0.01$ ). In the presence of $0.15 \mathrm{mg} / \mathrm{L} \mathrm{EB}$, the content of genuine anthocyanins in regenerant plants decreased reliably at $P<0.05$.

When IAA alone was present in the nutrient medium (Table 1, treatment 3 ), we observed a reliable (at $P<0.01$ ) 1.8-fold increase in the height of regenerant plants and a decrease in the content of anthocyanin pigments. The content of GA reduced by 1.6 times, and the content of LA and TAP decreased by 1.4 times.

The combination of EB with 2iP and IAA (Table 1, treatments $8-16)$ caused in all cases a reliable $(P<$ $0.01)$ increase in reproduction coefficients $\mathrm{RC}_{\mathrm{S}}$ and $\mathrm{RC}_{\mathrm{E}}$. The greatest reproduction coefficients were detected in regenerant plants cultured in the following treatments: treatment 10 (cytokinin : auxin $=7: 1$; $\mathrm{RC}_{\mathrm{S}}=6.5 ; \mathrm{RC}_{\mathrm{E}}=9.2$ ) and treatment 14 (cytokinin : auxin $\left.=4: 1 ; \mathrm{RC}_{\mathrm{S}}=5.4 ; \mathrm{RC}_{\mathrm{E}}=9.8\right)$. The combination of EB with $2.0 \mathrm{mg} / \mathrm{L} 2 \mathrm{iP}$ (both in the presence and in the absence of IAA, treatments $11-19$ in Table 1) always caused a reliable $(P<0.01) 4$ - to 8.5 -fold increase in the weight of regenerant plants. The regen- 
Table 3. Variability of main bioproductive parameters for the regenerant plants of highbush blueberry (cv. Brigitta blue) in vitro in the presence of EB at various concentrations

\begin{tabular}{|c|c|c|c|c|c|c|c|c|c|c|c|c|}
\hline \multirow[t]{2}{*}{ Treatment } & \multicolumn{3}{|c|}{$\mathrm{RC}_{\mathrm{S}}$} & \multicolumn{3}{|c|}{$\mathrm{RC}_{\mathrm{E}}$} & \multicolumn{3}{|c|}{ Plant height, $\mathrm{cm}$} & \multicolumn{3}{|c|}{$\begin{array}{l}\text { Weight of regenerant } \\
\text { plant, } \mathrm{g}\end{array}$} \\
\hline & $\mathrm{EB}_{0.05}$ & $\mathrm{~EB}_{0.15}$ & $\mathrm{~EB}_{0.25}$ & $\mathrm{~EB}_{0.05}$ & $\mathrm{~EB}_{0.15}$ & $\mathrm{~EB}_{0.25}$ & $\mathrm{~EB}_{0.05}$ & $\mathrm{~EB}_{0.15}$ & $\mathrm{~EB}_{0.25}$ & $\mathrm{~EB}_{0.05}$ & $\mathrm{~EB}_{0.15}$ & $\mathrm{~EB}_{0.25}$ \\
\hline $2 \mathrm{iP}_{7.25}+\mathrm{IAA}_{1.00}$ & 4.7 & 4.3 & $6.5 * *$ & 6.9 & 6.2 & $9.2 * *$ & 1.00 & 0.99 & 0.99 & 0.03 & 0.04 & 0.03 \\
\hline $2 \mathrm{iP}_{2.00}+\mathrm{IAA}_{0.50}$ & $5.4 *$ & 4.1 & 3.9 & $9.8 * *$ & $8.0 *$ & 6.9 & $1.55 * *$ & $1.71 * *$ & $1.72 * *$ & $0.07 * *$ & $0.08 * *$ & $0.09 * *$ \\
\hline $2 \mathrm{iP}_{2.00}+\mathrm{IAA}_{1.00}$ & 4.0 & $5.0 *$ & 3.2 & 8.2 & $8.0 *$ & 5.2 & $1.82 * *$ & $1.39 * *$ & $1.49 * *$ & $\mathbf{0 . 0 7 * *}$ & $0.13 * *$ & $0.10 * *$ \\
\hline $2 \mathrm{iP}_{2.00}$ & $5.1 *$ & 3.3 & 3.9 & 7.4 & 6.2 & 6.7 & $1.40 * *$ & $1.52 * *$ & $1.65 * *$ & $0.09 * *$ & $0.08 * *$ & $0.07 * *$ \\
\hline $\mathrm{LSD}_{0.05}$ & 0.5 & 0.5 & 0.5 & 1.4 & 1.4 & 1.4 & 0.09 & 0.09 & 0.09 & 0.01 & 0.01 & 0.01 \\
\hline $\mathrm{LSD}_{0.01}$ & 0.8 & 0.8 & 0.8 & 2.1 & 2.1 & 2.1 & 0.13 & 0.13 & 0.13 & 0.02 & 0.02 & 0.02 \\
\hline
\end{tabular}

Note: Bold type shows the greatest values of parameters. Asterisks * and ** mark significantly different values at $P<0.05$ and $P<0.01$, respectively. The same meaning of asterisks applies to Table 4.

Table 4. Variability of the content of anthocyanin pigments in regenerant plants of highbush blueberry (cv. Brigitta blue) in vitro in the presence of EB at various concentrations

\begin{tabular}{l|c|c|c|c|c|c|c|c|c}
\hline \multirow{2}{*}{ Treatment } & \multicolumn{3}{|c|}{ GA, mg\% } & \multicolumn{3}{c|}{ LA, mg\% } & \multicolumn{3}{c}{ TAP, mg\% } \\
\cline { 2 - 10 } & $\mathrm{EB}_{0.05}$ & $\mathrm{~EB}_{0.15}$ & $\mathrm{~EB}_{0.25}$ & $\mathrm{~EB}_{0.05}$ & $\mathrm{~EB}_{0.15}$ & $\mathrm{~EB}_{0.25}$ & $\mathrm{~EB}_{0.05}$ & $\mathrm{~EB}_{0.15}$ & $\mathrm{~EB}_{0.25}$ \\
\hline $2 \mathrm{iP}_{7.25}+\mathrm{IAA}_{1.00}$ & 601 & 296 & 537 & $\mathbf{4 5 6 3}_{*} *$ & 2798 & $\mathbf{4 2 9 6}^{* *}$ & $\mathbf{5 1 6 4} * *$ & 3095 & $\mathbf{4 8 3 2} * *$ \\
$2 \mathrm{iP}_{2.00}+\mathrm{IAA}_{0.50}$ & 574 & $\mathbf{1 3 1 6} * *$ & $\mathbf{1 1 8 0} * *$ & 3016 & 2830 & 3578 & 3591 & $\mathbf{4 1 4 6 * *}$ & $\mathbf{4 7 5 9} * *$ \\
$2 \mathrm{iP}_{2.00}+\mathrm{IAA}_{1.00}$ & $\mathbf{6 9 4} * *$ & $\mathbf{7 7 3} * *$ & $\mathbf{1 1 3 3} * *$ & 3647 & 2859 & 3321 & 4341 & $\mathbf{3 6 3 3} * *$ & 4454 \\
$2 \mathrm{iP}_{2.00}$ & $\mathbf{6 8 7 * *}$ & $\mathbf{1 1 8 0} * *$ & $\mathbf{8 9 3} * *$ & 3094 & $\mathbf{3 4 1 3} * *$ & 3599 & 3781 & $\mathbf{4 5 9 3} * *$ & 4492 \\
$\mathrm{LSD}_{0.05}$ & 41 & 41 & 41 & 105 & 105 & 105 & 122 & 122 & 122 \\
$\mathrm{LSD}_{0.01}$ & 57 & 57 & 57 & 143 & 143 & 143 & 166 & 166 & 166 \\
\hline
\end{tabular}

Note: Bold type shows the peak values of parameters.

erants accumulated the greatest weight in the following treatments: treatment 12 (cytokinin : auxin $=2: 1$, the weight of individual regenerated plants $0.134 \mathrm{~g}$ ) and treatment 13 (cytokinin : auxin $=2: 1$, the weight of a regenerated plant $0.100 \mathrm{~g}$ ). The combination of $\mathrm{EB}$ with $2.0 \mathrm{mg} / \mathrm{L} \mathrm{2iP}$ (both in the presence and absence of IAA, treatments 11-19 in Table 1) always caused a reliable $(P<0.01) 2$ - to 4.5 -fold increase in GA content in the regenerant plants. The greatest GA content was detected in regenerant plants grown on media of the following treatments: treatment 15 (cytokinin : auxin $=4: 1$; GA content $1316 \mathrm{mg} \%$ ); treatment 13 (cytokinin : auxin = 2: 1; GA content $1133 \mathrm{mg} \%$ ); treatment 16 (cytokinin : auxin $=4: 1$; GA content 1180 $\mathrm{mg} \%$ ); treatment 18 (GA content $1180 \mathrm{mg} \%$ ). After comparing the results obtained in treatments 8-10 (cytokinin : auxin $=7: 1), 11-13$ (cytokinin : auxin $=$ $2: 1$ ), and 14-16 (cytokinin : auxin = 4:1), we found that the greatest GA content was detected in the regenerant plants grown on media with the cytokinin : auxin ratio of $4: 1$ in the presence of elevated $(0.15$ and $0.25 \mathrm{mg} / \mathrm{L}$ ) concentrations of EB. The lowest concentration of GA was observed in the regenerant plants grown on media with $\mathrm{EB}$ at the cytokinin : auxin ratio of $7: 1$.
The greatest content of LA was detected in the regenerants grown on media of the following treatments: treatment 8 (cytokinin : auxin $=7: 1$; LA content $4563 \mathrm{mg} \%$ ) and treatment 10 (cytokinin : auxin = 7 : 1; LA content $4295 \mathrm{mg} \%$ ). The combination of $2 \mathrm{iP}$ and IAA with EB at concentrations of 0.05 and $0.25 \mathrm{mg} / \mathrm{L}$ caused an increase (reliable in most cases at $P<0.01)$ in LA content in regenerant plants, whereas the combination of $2 \mathrm{iP}$ and IAA with EB at concentration of $0.15 \mathrm{mg} / \mathrm{L}$ brought about a reliable decrease $(P<0.05)$ in the content of LA in the regenerant plants.

The presence of EB in the nutrient media caused a reliable (usually at $P<0.01$ ) increase in TAP content in regenerant plants in all the treatments except for treatments 5 and 9 (Table 1).

Comparison of variability of bioproductive parameters in the regenerant plants produced on nutrient media with EB in combination with phytohormones 2iP and IAA (Tables 3,4 ) revealed the additivity of EB, 2iP, and IAA effects in most cases. The additivity appeared usually upon the combination of $0.15 \mathrm{mg} / \mathrm{L}$ EB (moderate concentration) with $2.0 \mathrm{mg} / \mathrm{L} \mathrm{2iP} \mathrm{(low}$ concentration) in the absence or presence of IAA (at concentrations of 0.5 or $1.0 \mathrm{mg} / \mathrm{L}$ ), i.e., at cytokinin : 
auxin ratios equal to $2: 0,2: 1$, and $4: 1$. Upon elevation of $2 \mathrm{iP}$ concentration to $7.25 \mathrm{mg} / \mathrm{L}$ (treatments 8 10 , cytokinin : auxin $=7: 1$ ), the additivity effect was usually observed in the presence of high concentration of EB $(0.25 \mathrm{mg} / \mathrm{L})$.

The greatest reproduction coefficients $\left(\mathrm{RC}_{\mathrm{S}}\right.$ and $\mathrm{RC}_{\mathrm{E}}$ ) were observed in descending order in regenerant plants grown in the treatments 10 (cytokinin : auxin $=$ $7: 1), 14$ (cytokinin : auxin $=4: 1$ ), and 12 (cytokinin : auxin $=2: 1)($ Table 3$)$. When $2.0 \mathrm{mg} / \mathrm{L} 2 \mathrm{iP}$ was combined with low $(0.05 \mathrm{mg} / \mathrm{L})$ concentration of $\mathrm{EB}$ (treatment 17), the regenerants formed numerous shoots that were unable to produce mature explants consisting of at least two metamers. When $2.0 \mathrm{mg} / \mathrm{L}$ $2 \mathrm{iP}$ and $0.5 \mathrm{mg} / \mathrm{L}$ IAA were combined with moderate $(0.15 \mathrm{mg} / \mathrm{L})$ concentration of EB (treatment 15$)$, the shoot formation occurred at a moderate rate but the length of shoots and the number of internodes sufficed to produce fairly numerous mature explants (Table 3).

Analysis of reproduction coefficients has shown two effects (Table 3). First, at high concentration of $2 \mathrm{iP}(7.25 \mathrm{mg} / \mathrm{L})$, the reproduction coefficients $\left(\mathrm{RC}_{\mathrm{S}}\right.$ and $\mathrm{RC}_{\mathrm{E}}$ ) in the regenerant plants attained their maxima at EB concentration of $0.25 \mathrm{mg} / \mathrm{L}$. Second, at low concentration of $2 \mathrm{iP}(2.0 \mathrm{mg} / \mathrm{L})$, the reproduction coefficients $\left(\mathrm{RC}_{\mathrm{S}}\right.$ and $\left.\mathrm{RC}_{\mathrm{E}}\right)$ were usually maximal at low concentration of EB $(0.05 \mathrm{mg} / \mathrm{L})$. At cytokinin : auxin ratio of $4: 1(2.0 \mathrm{mg} / \mathrm{L} 2 \mathrm{iP}$ and $0.5 \mathrm{mg} / \mathrm{L} \mathrm{IAA})$, the reproduction coefficients $\left(\mathrm{RC}_{\mathrm{S}}\right.$ and $\left.\mathrm{RC}_{\mathrm{E}}\right)$ decreased with the increase in EB concentration.

No less important additive effects of phytohormones were established by analyzing variability of height and weight of regenerant plants (Table 3). When the low concentration of $2 \mathrm{iP}(2.0 \mathrm{mg} / \mathrm{L})$ was combined with EB, an increase in EB concentration promoted the increase in height and caused weight reduction in regenerant plants. When IAA was added to the medium at concentration of $0.5 \mathrm{mg} / \mathrm{L}$, an increase in EB concentration enhanced the height and weight of regenerant plants. When IAA concentration in the medium was further increased to $1.0 \mathrm{mg} / \mathrm{L}$, an increase in EB concentration caused the decrease in height and the rise in weight of regenerant plants. At a high concentration of $2 \mathrm{iP}(7.25 \mathrm{mg} / \mathrm{L})$ combined with $1.0 \mathrm{mg} / \mathrm{L}$ IAA and various concentrations of $\mathrm{EB}$, the height and weight of regenerant plants were inferior to those in regenerants grown at low concentration of $2 \mathrm{iP}$ $(2.0 \mathrm{mg} / \mathrm{L})$ and remained almost unchanged with the increase in EB concentration (Table 3).

Analysis of variability of anthocyanin pigment content in the regenerant plants grown in the presence of EB and various concentrations of other phytohormones also revealed some important features (Table 4). It is known that anthocyanins, being the secondary metabolites of flavonoid group, not only confer specific color to blueberry fruits but also exhibit valuable pharmacological properties such as antioxidant, adaptogenic, spasmolytic, and anti-inflammatory activities. At low concentration of $2 \mathrm{iP}(2.0 \mathrm{mg} / \mathrm{L})$ applied in combination with EB, the GA content in regenerant plants was elevated, with the peak value $(1180 \mathrm{mg} \%)$ attained at moderate concentration of EB $(0.15 \mathrm{mg} / \mathrm{L})$.

The addition of $0.50 \mathrm{mg} / \mathrm{L}$ IAA to the medium containing $2.0 \mathrm{mg} / \mathrm{L} 2 \mathrm{iP}$ caused a decrease in the content of GA in regenerant plants at low concentration of EB $(0.05 \mathrm{mg} / \mathrm{L})$ and significantly elevated GA content at higher concentrations of EB. Like in the previous case, the peak content of GA (1316 $\mathrm{mg} \%)$ was observed at EB concentration of $0.15 \mathrm{mg} / \mathrm{L}$. The further increase in IAA concentration to $1.0 \mathrm{mg} / \mathrm{L}$ brought about some decrease in GA content in regenerant plants; however, the GA level remained reliably high (Table 4). In this case, the content of GA in the regenerant plants increased with the $\mathrm{EB}$ concentration in the medium. At high concentration of $2 \mathrm{iP}$ $(7.25 \mathrm{mg} / \mathrm{L})$ in the presence of $1.0 \mathrm{mg} / \mathrm{L} \mathrm{IAA}$ and $\mathrm{EB}$, a decrease in the content of GA in regenerant plants was even more pronounced. The lowest content of GA was observed at $0.15 \mathrm{mg} / \mathrm{L} \mathrm{EB}\left(\mathrm{GA}_{\mathrm{EB} 0.15}=296 \mathrm{mg} \%\right)$. This low content was close to the GA level in regenerant plants cultured on the hormone-free medium $\left(\mathrm{GA}_{\mathrm{WPM}}=254 \mathrm{mg} \%\right.$, Table 2$)$. The content of GA rose when EB concentration was increased to $0.25 \mathrm{mg} / \mathrm{L}$ $\left(\mathrm{GA}_{\mathrm{EB}} 0.25=537 \mathrm{mg} \%\right)$ or was decreased to $0.05 \mathrm{mg} / \mathrm{L}$ $\left(\mathrm{GA}_{\mathrm{EB} 0.05}=601 \mathrm{mg} \%\right)$.

The greatest LA content in the regenerant plants was observed on the media with $7.25 \mathrm{mg} / \mathrm{L} 2 \mathrm{iP}$ and $1.0 \mathrm{mg} / \mathrm{L}$ IAA combined with low $(0.05 \mathrm{mg} / \mathrm{L})$ or high $(0.25 \mathrm{mg} / \mathrm{L})$ concentrations of EB. In these treatments, the LA levels were as high as 4563 and $4295 \mathrm{mg} \%$, respectively (Table 4). At low concentration of $2 \mathrm{iP}$ $(2.0 \mathrm{mg} / \mathrm{L})$, an increase in EB concentration promoted accumulation of LA to peak values attained in the presence of $0.15 \mathrm{mg} / \mathrm{L} \mathrm{EB} \mathrm{(3413} \mathrm{mg} \%)$ and $0.25 \mathrm{mg} / \mathrm{L}$ EB (3599 mg\%). When IAA (0.50 and $1.0 \mathrm{mg} / \mathrm{L}$ ) was added to the medium and $2 \mathrm{iP}$ concentration was increased to $7.25 \mathrm{mg} / \mathrm{L}$ in the presence of $1.0 \mathrm{mg} / \mathrm{L}$ IAA and $0.15 \mathrm{mg} / \mathrm{L} \mathrm{EB}$, the LA content in regenerant plants decreased considerably. In this case, the lowest content of LA, like that of genuine anthocyanins, was observed in the regenerants grown on the media with $7.25 \mathrm{mg} / \mathrm{L} 2 \mathrm{iP}, 1.0 \mathrm{mg} / \mathrm{L}$ IAA, and $0.15 \mathrm{mg} / \mathrm{L}$ EB (Table 4).

The greatest content of TAP was observed in regenerant plants upon combination of $7.25 \mathrm{mg} / \mathrm{L} 2 \mathrm{iP}$ with $1.0 \mathrm{mg} / \mathrm{L}$ IAA and $0.05 \mathrm{mg} / \mathrm{L}$ EB $(5164 \mathrm{mg} \%)$ or $7.25 \mathrm{mg} / \mathrm{L} 2 \mathrm{iP}$ with $1.0 \mathrm{mg} / \mathrm{L}$ IAA and $0.25 \mathrm{mg} / \mathrm{L} \mathrm{EB}$ (4832 $\mathrm{mg} \%$ ), or $2.0 \mathrm{mg} / \mathrm{L} 2 \mathrm{iP}$ with $0.50 \mathrm{mg} / \mathrm{L}$ IAA and $0.25 \mathrm{mg} / \mathrm{L} \mathrm{EB}(4759 \mathrm{mg} \%)$, or $2.0 \mathrm{mg} / \mathrm{L} 2 \mathrm{iP}$ and $0.15 \mathrm{mg} / \mathrm{L} \mathrm{EB}$ (4593 $\mathrm{mg} \%$ ) (Table 4). We found that the TAP level decreased considerably in the regenerant plants grown on the media with $0.15 \mathrm{mg} / \mathrm{L} \mathrm{EB}$ when $2 \mathrm{iP}$ concentration was increased from 2.0 to $7.25 \mathrm{mg} / \mathrm{L}$. This effect was even more evident in the presence of IAA concentrations increasing in the range from 0.5 to $1.0 \mathrm{mg} / \mathrm{L}$ (Table 4 ). 


\section{DISCUSSION}

Analysis of variability of bioproductive parameters in the regenerant plants has shown the effect of additivity when EB was combined with $2 \mathrm{iP}$ and IAA. This effect was most pronounced in the presence of $0.15 \mathrm{mg} / \mathrm{L} \mathrm{EB}$ and $2.0 \mathrm{mg} / \mathrm{L} 2 \mathrm{iP}$ at the cytokinin : auxin ratios of $2: 0,2: 1$, and $4: 1$. When the concentration of $2 \mathrm{iP}$ was increased to $7.25 \mathrm{mg} / \mathrm{L}$, the additivity was observed upon the combination of $2 \mathrm{iP}$ with higher concentration of EB $(0.25 \mathrm{mg} / \mathrm{L}$, see Tables 2,4$)$. Some researchers detected synergism of brassinosteroids, active auxins, and $\mathrm{Ca}^{2+}$, and described the additive stimulation of ethylene production upon the use of these agents in combination with cytokinins [17-20].

Based on the results of our study, we recommend to use EB at concentrations of $0.05-0.15 \mathrm{mg} / \mathrm{L}$, with lowered expenditures of cytokinin $(2.0 \mathrm{mg} / \mathrm{L} 2 \mathrm{iP})$, for the efficient in vitro micropropagation (parameters $\mathrm{RC}_{\mathrm{S}}$ and $\mathrm{RC}_{\mathrm{E}}$, Tables 2, 3).

The effects of EB, 2iP, and IAA combinations on the height and weight of regenerant plants are ambiguous and contradictory. The presence of $2 \mathrm{iP}$ in the medium at low $(2.0 \mathrm{mg} / \mathrm{L})$ concentration on the background of elevated EB content caused the increase in height but the decrease in weight of the regenerant plants. The addition to the medium of IAA ( 0.5 and $1.0 \mathrm{mg} / \mathrm{L}$ ), combined with low concentration of EB $(0.05 \mathrm{mg} / \mathrm{L})$, brought about an increase in height and weight of the regenerant plants, while application of IAA in combination with EB at moderate $(0.15 \mathrm{mg} / \mathrm{L})$ and high $(0.25 \mathrm{mg} / \mathrm{L})$ concentrations diminished the height and elevated the weight of regenerant plants (Table 3).

Analysis of anthocyanin content suggests that almost all investigated combinations of $\mathrm{EB}, 2 \mathrm{iP}$, and IAA were stressful for regenerant plants (Table 4). Brassinosteroids (BS) regulate plant responses to biotic and abiotic stresses and responses to the presence of other phytohormones. They launch a succession of events, such as signal perception, production of secondary messengers, changes in intracellular $\mathrm{Ca}^{2+}$ fluxes, accumulation of reactive oxygen species (oxidative stress), phosphorylation of proteins, and transcription of genes needed for synthesis of ABA, ethylene, and jasmonic and salicylic acids [5, 21]. Brassinosteroids and ABA interact and regulate expression of hundreds of genes governing various biological processes. Exogenous ABA negates the BS-mediated effects. The ABA- and BS-initiated signaling cascades are likely to intersect after the perception of BS signal but before the activation of target genes, with the majority of BS target genes being regulated by $\mathrm{ABA}$. Under stress, ABA synthesis is activated. ABA disturbs the BS signal transduction; in this case, the BS signal transduction may be regulated via protein phosphatases of PP2C family including ABI1 and ABI2 [22].

Earlier studies established that BS induce and regulate expression of certain antioxidant genes and acti- vate key antioxidant enzymes, including superoxide dismutase, peroxidase, and catalase [23-26]. In plant organisms exposed to stresses, BS are capable of inducing and regulating the operation of antioxidant systems [27].

It is known that anthocyanins are strong antioxidants. According to our data, the additive interactions of phytohormones promote the accumulation of anthocyanins in regenerant plants cultured on agarized nutrient media supplemented with cytokinin (2iP), EB, and IAA and, to a lesser degree, in the absence of IAA (Tables 2, 4).

In addition, a synergistic action of BS and auxins on growth regulation and cell proliferation was shown. Nevertheless, the kinetics of these processes differed under the action of BS and auxins. Unlike the auxin effect, which appeared without delay and rapidly attained its maximum, the BS-mediated response was delayed and reached the maximum much later. Synergism was often observed upon repeated treatments with two hormones [4]. In this case, BS elevated the sensitivity of arabidopsis seedlings to auxin, so that the joint treatment with two hormones considerably elevated the intensity and duration of gene expression [28].

The role of auxin and BS in regulation of cell growth may be related to reorganization of cytoskeleton. In cells of arabidopsis hypocotyls, the cellulose fibrils are arranged as parallel rings at the right angle to the apical-basal cell axis and facilitate the extension of this axis. The orientation of newly synthesized fibrils depends on orientation of underlying cortical microtubules. Both the density and orientation of cortical microtubules depend, at least partly, on the initial BS-mediated pathway of signal transduction, because, in the BS mutants with reduced $\beta$-tubulin gene expression, the cortical microtubules were arranged in a random manner. These effects are negated by exogenous treatment with BS. In hypocotyls of wild-type arabidopsis, the auxin treatment initiated rearrangements of cortical microtubules similarly to the treatment with BS. Both IAA and BS induce expression of the genes that encode the cell wall-degrading enzymes [4].

Brassinosteroids were found to increase the frequency of cell divisions in the presence of auxin and cytokinin; furthermore, the presence of BS was a prerequisite for cell proliferation in shoots and roots. In callus cultures, BS can replace cytokinins and, thereby, ensure cell-cycle progression. Probably, the presence of BS extends the range of auxin activities and makes it possible to exclude cytokinin from the callus culture. Directionality of the effects of auxins and BS depends on their concentration. At low concentrations, phytohormones act as activators; at high concentrations, as inhibitors. Thus, minor changes in hormone concentration can strongly modify morphological responses such as cell elongation [4].

Recent studies [4] have shown that changes in gene expression initiated by auxin and BS may overlap, so that the same targets can perceive both the auxin- 
based and BS signals. Such target genes are usually more responsive to auxin than to $\mathrm{BS}$; on the whole, the $\mathrm{BS}$-induced transcription is less pronounced. On the contrary, the auxin-induced transcription is always quicker and has pronounced amplitude. The slow development of BS response may signify that the BSinduced transcription includes some intermediate stages. For instance, the BS effects on auxin-induced genes may be mediated by the BS-induced genes $A U X / I A A$. In the presence of BS, the auxin level changes insignificantly, because BS does not accelerate auxin biosynthesis but potentiates the effect of background auxin concentrations.

Genes of BS biosynthesis are governed by the molecules of BS and auxin. For instance, BRX (BREVIS $R A D I X)$, a target gene for auxin, encodes a protein that accelerates biosynthesis of BS for the purpose of its maintenance on the level sufficient for causing an auxin-induced response. The genes encoding the enzymes restricting the rate of BS biosynthesis are auxin-induced ones. Thus, on the one hand, the BS level does not restrict auxin biosynthesis but limits the auxin-induced responses. On the other hand, the feedback auxin control contributes to the maintenance of a certain homeostatic BS level. At the same time, brassinosteroids partly govern expression of genes encoding proteins that lower the level of auxin by affecting the rate of its polar transport [4].

Some researchers [29] reported that the content of free and bound forms of $\mathrm{ABA}$ and IAA increases in the presence of $\mathrm{EB}$ and $\mathrm{Cu}^{2+}$, this effect being most pronounced in the case of ABA. When the plants were treated with $\mathrm{EB}$ and $\mathrm{Cu}^{2+}$, the levels of phytochelatin, ascorbic acid, total phenols, and proline were raised, which ensured strengthening of antioxidant activity. In our study, $\mathrm{Cu}^{2+}$ and $\mathrm{Ca}^{2+}$ ions present in the nutrient medium for culturing the regenerant plants of Brigitta blue were apparently able to cooperate with EB in exerting joint influence on variability of bioproductive parameters in highbush blueberry in vitro.

It was experimentally shown that the rise in EB concentration activates photosynthesis and elevates the content of chlorophylls $a$ and $b[30,31]$. The presence of BS and auxin accelerates ethylene biosynthesis. In many cases, such as reassembling of microtubules or tropisms, ethylene can replace auxin and BS. Auxins and BS control the level of ethylene, showing synergistic interaction via regulation of transcription of the genes coding for enzymes that restrict ethylene synthesis [4]. Brassinosteroids accelerate ethylene synthesis at the stage between $\mathrm{S}$-adenosyl methionine and 1-aminocyclopropane-1-carboxylic acid [18, 25]. Ethylene is known to stimulate synthesis of ABA that accelerates cell senescence and suppresses biochemical processes, ABA being an antagonist of auxins, cytokinins, and gibberellins.

Elevation of ethylene concentration in stressed plant tissues plays a protective role. For instance, stress-related ethylene release induces synthesis of protective phytoalexins and enzyme chitinase that destroy cell walls of fungi (including pathogenic fungi). It is possible that exactly such BS effect accounts for the effectiveness of EB application at the stage of shoot initiation in the regenerant plants of highbush blueberry varieties in the course of its axenic culturing in vitro. This effectiveness is evident form the reliable increase in the number of actively regenerating axenic explants [11].

Our study shows that the addition of exogenous EB to the agarized macronutrient- and micronutrientcontaining medium (WPM) for in vitro propagation of $V$. corymbosum regenerant plants, together with the addition of cytokinin (2iP) and auxin (IAA), brings about changes in quantitative and qualitative characteristics of growth and development of regenerant plants (explants) in vitro. The established increase in reproduction coefficients for regenerant plants in the case of combination of $2 \mathrm{iP}$ and IAA with low concentrations of EB opens wide possibilities for practical application of EB.

\section{REFERENCES}

1. Hayat, S. and Ahmad, A., Brassinosteroids: A Class of Plant Hormones, Berlin: Springer-Verlag, 2010.

2. Hothorn, M., Belkhadir, Y., Dreux, M., Dabi, T., Noel, J.P., Wilson, I.A., and Chory, J., Structural Basis of Steroid Hormone Perception by the Receptor Kinase BRI1, Nature, 2011, vol. 474, pp. 467-471.

3. She, J., Han, Zh., Kim, T., Wang, J., Cheng, W., Chang, J., Shi, Sh., Wang, J., Yang, M., Wang, Zh., and Chai, J., Structural Insight into Brassinosteroid Perception by BRI1, Nature, 2011, vol. 474, pp. 472-476.

4. Hardtke, Ch.S., Dorcey, E., Osmont, K.S., and Sibout, R., Phytohormone Collaboration: Zooming in on Auxin-Brassinosteroid Interactions, Trends Cell Biol., 2007, vol. 17, pp. 485-492.

5. Mussig, C. and Altmann, T., Physiology and Molecular Mode of Action of Brassinosteroids, Plant Physiol. Biochem., 1999, vol. 37, pp. 363-372.

6. Yin, Y., Wang, Zh., Mora-Garcia, S., Li, J., Yoshida, Sh., Asami, T., and Chory, J., BES1 Accumulates in the Nucleus in Response to Brassinosteroids to Regulate Gene Expression and Promote Stem Elongation, Cell, 2002, vol. 109, pp. 181-191.

7. Yin, Y., Vafeados, D., Tao, Y., Yoshida, Sh., Asami, T., and Chory, J., A New Class of Transcription Factors Mediates Brassinosteroid-Regulated Gene Expression in Arabidopsis, Cell, 2005, vol. 120, pp. 249-259.

8. Rupasova, Zh.A., Golubika vysokoroslaya: otsenka adaptatsionnogo potentsiala pri introduktsii $v$ usloviyakh Belarusi (Vaccinium corymbosum L.: Adaptive Potential Rating during Introduction in Belarus), Minsk: Belarus. nauka, 2007.

9. Volotovich, A.A., Results of Activities of Research Laboratory on Cell Technologies in Plant Cultivation in "Polesskii Gos. Univ." as the Model for Applied Biotechnology Development in the Institute of Higher Education, Mater. V Mezhd. Nauch.-Prakt. Konf. "Ustoichivoe Razvitie Ekonomiki: Sostoyanie, Problemy, 
Perspektivy" (Proc. V Int. Conf. "Sustainable Development of Economics: State, Problems, and Perspectives”, Pinsk, April 28-29, 2011), Pinsk: Polessk. Gos. Univ., 2011, part 1, pp. 286-288.

1 10. Sidorovich, E.A. and Kutas, E.N., Klonal'noe mik2 rorazmnozhenie novykh plodovo-yagodnykh rastenii (Clonal Micropropagation of New Fruit Plants), Minsk: Navuka i tekhnika, 1996.

3 11. Gleb, E.P., Guk, E.S., Beda, I.O., Kudryashova, O.A., and Volotovich, A.A., Increase in the Regeneration Activity of Vaccinium corymbosum L. In Vitro in the Presence of 24-Epibrassinolid, Mater. VMezhd. Molod. Nauch.-Prakt. Konf. "Nauchnyi potentsial molodezhiBudushchemu Belarusi" (Proc. VInt. Youth Conf. "Scientific Potential of Young Researchers-for the Future of Belarus"), Pinsk: Polessk. Gos. Univ., 2011, part 3, pp. 227-229.

12. Trigiano, R.N. and Gray, D.J., Plant Tissue Culture Concepts and Laboratory Exercises, Boca Raton: CRC, 2000.

4 13. Shnaidman, L.O. and Afanas'eva, V.S., Method for Anthocyanin Determination, Ref. i dokl. soobshch. IX Mendeleevskii s"ezd po obshchei i prikladnoi khimii (Abst. and Proc. IX Mendeleev Congr. General and Applied Chemistry), Moscow, 1965, pp. 79-80.

5 14. Swain, F. and Hillis, W., The Phenolic Constituents of Prunus domestica. I. The Quantitative Analysis of Phenolic Constituents, J. Sci. Food Agric., 1959, vol. 10, pp. 63-68.

15. Dospekhov, B.A., Metodika polevogo opyta (Methodology of Field Experiments), Moscow: Agropromizdat, 1985.

16. Borovikov, V.P., STATISTIKA: Iskusstvo analiza dannykh na komp'yutere (STATISTICS: The Art of Data Analysis Using Computer), St. Petersburg: Piter, 2001.

17. Arteca, R.N., Tsai, D.S., Schlagenhaufer, C.D., and Mandava, N.B., The Effects of Brassinolide on AuxinInduced Ethylene Production by Etiolated Mung Bean Segments, Physiol. Plant., 1983, vol. 59, pp. 539-544.

18. Arteca, R.N., Rooting, Plant Growth Substances. Principles and Applications, Arteca, R.N., Ed., New York: Chapman and Hall, 1995, pp. 127-145.

19. Swarup, R., Parry, G., Graham, N., Allen, T., and Bennett, M., Auxin Cross-Talk: Integration of Signaling Pathways to Control Plant Development, Plant Mol. Biol., 2002, vol. 49, pp. 411-426.

20. Maureen, H., Hyun, S.C., and Kieber, J.J., Regulation of ACS Protein Stability by Cytokinin and Brassinosteroid, Plant J., 2009, vol. 57, pp. 606-614.
21. Ryabushkina, N.A., Synergism of Metabolite Action in Plant Responses to Stresses, Russ. J. Plant Physiol., 2005 , vol. 52, pp. 547-552.

22. Zhang, S., Cai, Z., and Wang, X., The Primary Signaling Outputs of Brassinosteroids Are Regulated by Abscisic Acid Signaling, Proc. Natl. Acad. Sci. USA, 2009, vol. 106, pp. 4543-4548.

23. Mazorra, L.M., Nunez, M., Hechovarria, M., Coll, F., and Sanchez-Blanco, M.J., Influence of Brassinosteroids on Antioxidant Enzymes Activity in Tomato under Different Temperatures, Biol. Plant., 2002, vol. 45, pp. 593-596.

24. Nunez, M., Mazzafera, P., Mazorra, L.M., Siqueira, W.J., and Zullo, M.A.T., Influence of Brassinosteroid Analogue on Antioxidant Enzymes in Rice Grown in Culture Medium with $\mathrm{NaCl}$, Biol. Plant., 2003, vol. 47, pp. 67-70.

25. Joo, S., Seo, Y.S., Kim, S.M., Hong, D.K., Park, K.Y., and Kim, W.T., Brassinosteroid Induction of AtACS4 Encoding an Auxin-Responsive 1-Aminocyclopropane-1-Carboxylate Synthase 4 in Arabidopsis Seedlings, Physiol. Plant., 2006, vol. 126, pp. 592-604.

26. Ogweno, J.O., Song, X.S., Shi, K., Hu, W.H., Mao, W.H.M., Zhou, Y.H., Yu, J.Q., and Nogues, S., Brassinosteroids Alleviate Heat-Induced Inhibition of Photosynthesis by Increasing Carboxylation Efficiency and Enhancing Antioxidant Systems in Lycopersicon esculentum, J. Plant Growth Regul., 2008, vol. 27, pp. 49-57.

27. Ashraf, M., Akram, N.A., Arteca, R.N., and Foolad, M.R., The Physiological, Biochemical and Molecular Roles of Brassinosteroids and Salicylic Acid in Plant Processes and Salt Tolerance, Crit. Rev. Plant Sci., 2010, vol. 29, pp. 162-190.

28. Vert, G., Walcher, C.L., Chory, J., and Nemhauser, J.L., Integration of Auxin and Brassinosteroid Pathways by Auxin Response Factor 2, Proc. Natl. Acad. Sci. USA, 2008, vol. 105, pp. 9829-9834.

29. Choudhary, S.P., Bhardwaj, R., Gupta, B.D., Dutt, P., Gupta, R.K., Biondi, S., and Kanwar, M., Epibrassinolide Induces Changes in Indole-3-Acetic Acid, Abscisic Acid and Polyamine Concentrations and Enhances Antioxidant Potential of Radish Seedlings under Copper Stress, Physiol. Plant., 2010, vol. 140, pp. 280-296.

30. Kalituho, L.N., Chaika, M.T., Mazhul, V.M., and Khripach, V.A., Effect of 24-Epibrassinolide on Pigment Apparatus Formation, Proc. Twenty-Third Annual Meeting of the Plant Growth Regulation Society of America, Calgary, 1996, pp. 36-40.

31. Swamy, K.N. and Rao, S.S.R., Effect of 24-Epibrassinolide on Growth, Photosynthesis, and Essential Oil Content of Pelargonium graveolens (L.) Herit, Russ. J. Plant Physiol., 2009, vol. 56, pp. 616-620.

SPELL: 1. Kutas, 2. plodovo, 3. Beda, 4. Afanas'eva, 5. Hillis 